Article

\title{
What Do University Students Know about Sustainable Development Goals? A Realistic Approach to the Reception of this UN Program Amongst the Youth Population
}

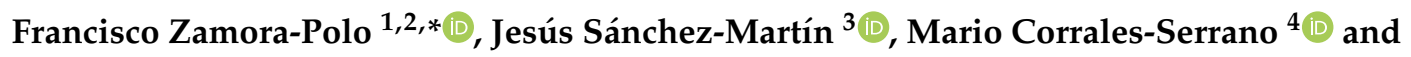 \\ Luis Espejo-Antúnez ${ }^{5}$ (D) \\ 1 Departamento de Ingeniería del Diseño, Escuela Politécnica Superior, Universidad de Sevilla, 41011 Sevilla, \\ Spain \\ 2 Energética y de los Materiales, Departamento de Ingeniería Mecánica, Escuela de Ingenierías Industriales, \\ Universidad de Extremadura, 06006 Badajoz, Spain \\ 3 Departamento de Didáctica de las Ciencias Experimentales y Matemáticas, Facultad de Educación, \\ Universidad de Extremadura, 06006 Badajoz, Spain \\ 4 Departamento de Didáctica de las Ciencias Sociales, Lengua y Literatura, Facultad de Educación, \\ Universidad de Extremadura, 06006 Badajoz, Spain \\ 5 Departamento de Terapeútica Médico-Quirúrgica, Facultad de Medicina, Universidad de Extremadura, \\ 06006 Badajoz, Spain \\ * Correspondence: fzpolo@us.es
}

Received: 3 May 2019; Accepted: 21 June 2019; Published: 27 June 2019

check for updates

\begin{abstract}
The Sustainable Development Goals (SDGs) constitute a working agenda for the international community with the aim of ensuring a better world for future generations. In this context, the development of competences related to SDGs is a challenge for Higher Education Institutions. Although there are several studies that address the relationship between SDGs and university teaching, the students' knowledge about this subject has not been set out yet. In order to evaluate students' knowledge, a questionnaire was designed, validated, and administered to students from different degrees. Statistical analysis showed a high reliability for the constructs (Smallest Cronbach's Alfa $=0.859)$. The results showed interesting insights, either with descriptive analysis or inferential ones. For example, a low knowledge, in a general way, of SDGs was identified in the whole sample; significant differences between the scores obtained in professional and personal implications of SDGs were also detected and several differences arose between Health and Education students, the latter being more professionally involved with SDGs than the rest of the students.
\end{abstract}

Keywords: SDG; higher education; competences; sustainability education; technology education; science education

\section{Introduction}

After the relative success of Millennium Development Goals (MDGs) [1], the international community has proposed a new framework: the Sustainable Development Goals (SDGs) [2]. The main objectives of SDGs are: to reduce poverty, protect the planet, and to ensure peace and security. To this end, 17 objectives, 169 targets, and 263 indicators have been formulated; their time horizon extends from 2015 to 2030 [2]. The three principal keys characteristics of SDGs are: (1) they are universal (all countries are included, both developing and developed ones), (2) they are indivisible (it is not possible to prioritize them, they must all be developed together), and (3) they are transformative (they try to 
convert challenge to opportunities) [2]; their 5 pillars are: people, prosperity, peace, partnership, and planet [2].

In previous research, some authors have pointed out that SDGs can be read in contradictory terms [3]. On the one hand, they can contribute to social transformation, but on the other hand, they can be read from a utilitarian perspective and they can contribute to maintain the current status quo [3].

Furthermore, the adoption of SDGs is not as fast as might be expected [4]. There is a certain lack of knowledge of the Sustainable Development Goals. For example, the Spanish Government has drawn up an agenda for the fulfilment of the SDGs (Agenda 2030) [5] but, according to a study by the "Centro de Investigaciones Sociológicas," only $10.8 \%$ of the Spanish population knew about it in January 2019 [6].

In order to achieve the Sustainable Development Goals, it is necessary to involve all stakeholders: administration, private companies, nongovernmental organizations, etc. [1,2,7]. In fact, the SDG declaration states that collaboration will require the implication of "all countries, all stakeholders and all people." [2]. In this sense, SDGs should be a common language for these actors to address the issue of Sustainability Human Development [4]. To make this possible a certain "asymmetrical bilingualism" is required. This expression was introduced by Hortal in the field of teaching ethics [8] and was used in specific studies linking ethics and higher education $[9,10]$. With this expression, what authors aim to express is the importance of language and knowledge of the fundamentals that are in the background of the Sustainable Development Goals: human rights, environmental sustainability, human development, justice, and peace, amongst others.

In this sense, there is no doubt that education is crucial for the achievement of the SDGs [11]. In fact, the inclusion of the MDGs in the various stages of education was one of the causes of its success [1]. Although education is directly related to Goal 4 (ensure inclusive and equitable quality education and promote lifelong education to create opportunities for all) [2], the presence of education is transversal to many of the SDGs [7]. In addition, at the different educational stages, training can be provided to raise awareness and promote the development of SDGs.

Higher education institutions play a very important role in the achievement of SDGs [12-15] and many authors have pointed out this relevance. Boni et al. [12] proposed a matrix for developing and evaluating university activities in post-2015 context. In this matrix, there are activities related to different fields: teaching, research, social engagement, university governance, and policy, as well as the university environment [12]. In this way, university activities can be oriented towards social transformation and the search for SDGs. Initiatives such as transdisciplinary research focused on social needs, knowledge transfer, or the use of teaching methodologies such as service learning can be examples of this transformative university [16].

Focusing on teaching, university students develop competences in their training. The term "competence" can be defined as the integration of knowledge, skills, and attitudes that can be applied in a specific context $[17,18]$. University education can be oriented towards the professional training of students (specific competences) or it can train students in an integrated way by developing specific competences and transversal competences [19-22]. Transversal competences, irrespective of its application in the professional field, are related to the exercise of active, critical, and committed citizenship [19-22]. One of the challenges of education is the assessment of competences, and in a special way, the assessment of transversal competences [23].

The fulfillment of the SDGs requires the training of students in both specific and transversal skills. For example, a mechanical engineering student must know the fundamentals of renewable energies (specific competences) and be aware of the impact of energy consumption on the environment (transversal competences).

Experiences related to teaching and promoting SDGs at the university context have been described previously [4,24-27]. However, to the best of our knowledge, students' previous knowledge related to SDGs has not been analyzed. This paper tries to fill this gap. An assessment of the knowledge of 
university students of SDGs can allow the following: (1) Correctly design actions to teach and promote SDGs; (2) Evaluate the impact of future actions; (3) Study the evolution of SDG knowledge over time.

The remainder of this article is organized as follows: in Section 2 theoretical backgrounds, research questions and the main goals of the article are developed; afterwards, methodology is described; results are presented in Section 4 and they are discussed in Section 5. Finally, the main conclusions are exposed in Section 6.

\section{Theoretical Backgrounds}

Figure 1 shows a schematic representation of the concepts addressed in this section. We understand that the promotion and teaching of SDGs at university should be understood within a broader concept of Education for Sustainable Human Development. Teaching and promoting the SDGs require the development of competences in students; these competencies must be worked on through strategies and teaching methodologies and they must be evaluated. In order to design a teaching-learning process for SDGs based on competences, it is necessary to know the students: previous knowledge, background, motivations, and so on.

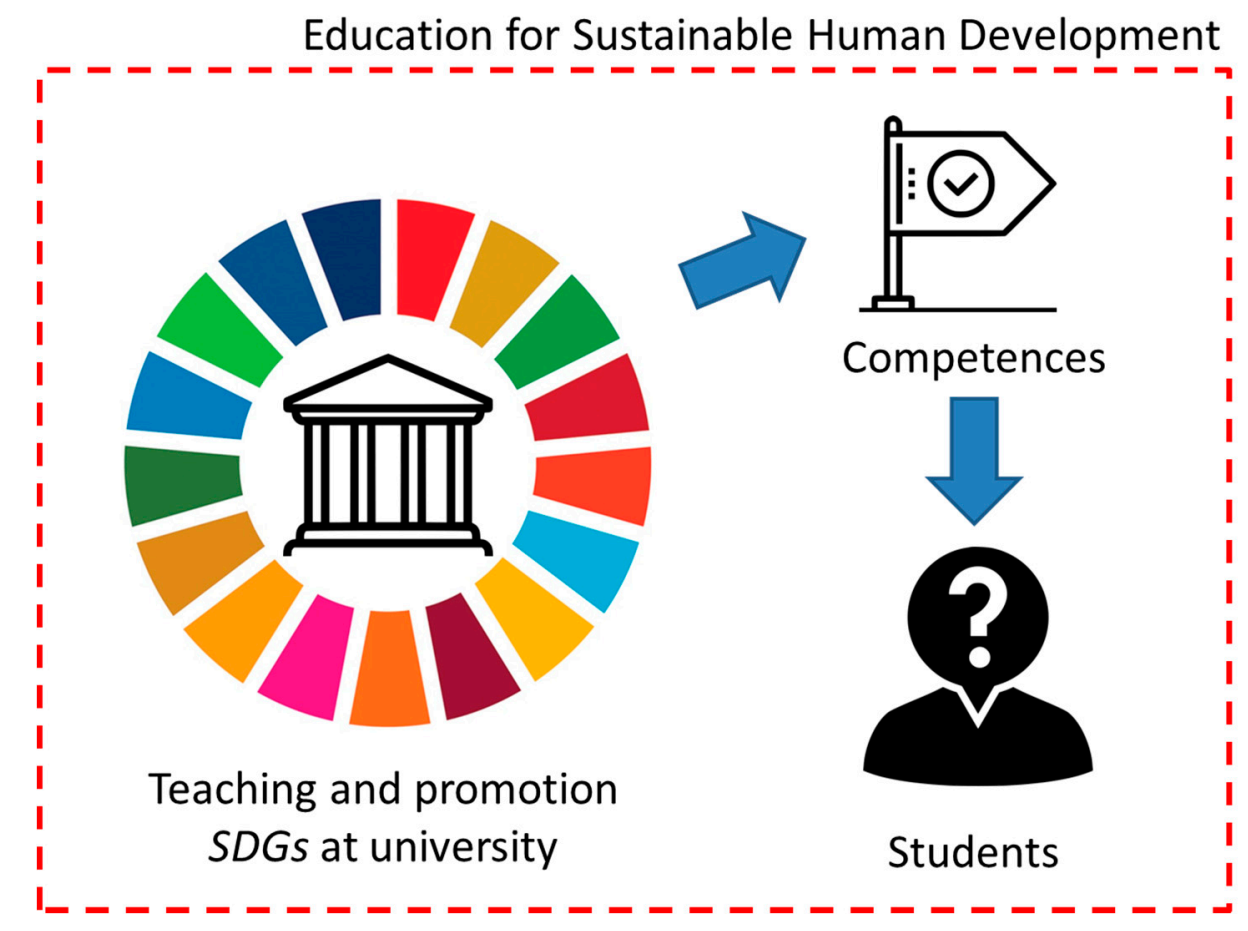

Figure 1. Main concepts developed in theoretical framework Source: own elaboration. Icon credits: www.onlinewebfonts/icon CC BY 3.0. SDGs: Sustainable Development Goals.

\subsection{Education for Sustainable Human Development}

The new paradigm of education for Sustainable Human Development has arisen recently and it includes several key concepts that should be defined prior to finding out the relationship between education and SDGs. We understand Human Development (HD) as the process of expansion of capabilities and real freedoms that people enjoy [28]. Furthermore, Sustainable Development (SD) can be defined as current development that does not jeopardize the development of future generations [29]. Sustainable Human Development (SHD) can be termed as: "the expansion of the substantive freedoms of people today while making reasonable efforts to avoid seriously compromising those of future generations" (p. 18) [30]. Education for Sustainable Human Development (ESHD) seeks to generate processes that qualify for SHD in all sectors of the population, covering both formal and informal education spaces. 
University has a crucial role in achieving SD and SHD [31,32]. There are different visions of university [33]: a producer of economic values; another model in which the university is a social elevator; and a university committed to building a fairer world. In a historical moment such as the present one signed by globalization, it is essential to train students in competences that enable them to be global citizens [33]. Numerous initiatives have been carried out in the field of teaching to promote SHD at the university level [34,35]. There are different methodologies to carry out this task [36,37]. The transversal development of ordinary subjects not directly linked to sustainability has been shown to be a viable and convenient option for carrying out this task [34]. In any case, the participation, motivation, and formation of academics are crucial for the success of this type of activities [27,32,34].

\subsection{Promotion and Teaching of SDGs at the University Level}

We agree with Boni et al. [12] that university is not excellent only for carrying out cutting-edge research. Other aspects such as teaching, commitment to society, governance, and the university environment should be included in the assessment of a university's activities [12]. In each and every one of these areas, the university can contribute to the construction of a fairer society and, therefore, to the construction of the SDGs [13].

Focusing on teaching, a university trains the professionals and citizens of society. This is why the bias of university education will have a radical importance in tomorrow's society. The challenge to address the SDGs must be transversal, involving the joint work of several disciplines and dialogue between different areas of the same discipline [13]. However, it must be a practical approach to reality [13]. The education and promotion of SDGs must be understood in the broader context of ESHD. Most of the authors consider that SDGs teaching should be understood in the context of a transformative education [7], which seeks to increase the capacities of students [12], in the perspective proposed by Sen [38] and Nussbaum [39].

Thus, Dlouhá et al. [7] developed a participatory research in order to propose a framework to teach SDGs. As a result of their research, they propose a holistic educational vision that integrates four domains: grounded, engaged, self-confident, and open [7].

Some works have described experiences of SDGs at the university level. Thus, SDGs have been dealt transversally in a joint master's degree in Russia and the United Kingdom [26]. This paper highlights some aspects that are a barrier to the cross-cutting implementation of the SDGs: time limitation, evaluation, and teacher training. In order to overcome these limitations, they proposed to create a common language and the establishment of governance that guarantees the success of the experience. Crespo et al. [24] analyzed a developed experience in a Master's of Thermal Engineering at the University of Vigo. The works developed in a course of the master are analyzed and authors proposed a rubric that includes technical, social, economic, and environmental aspects. It was focused on goals $7,8,12$, and 13. In general, the development of each of the aspects turned out to be unequal depending on the type of developed work. However, Albareda-Tiana et al. [40] studied different teaching methodologies in order to develop sustainable competence in preservice teaching training.

Recently, the use of Massive Open Online Courses (MOOCs) for teaching SDGs and promoting the sustainability development into the teacher training curricula has been analyzed [25] and major challenges to address education for sustainability in engineering studies have been studied [41]. Finally, the level of integration of SDGs by engineering professors committed to Education for Sustainable Human Development in their subjects has been studied by Lazzarini et al. [27]. This work showed that the most developed themes are those related to climate change (SDG 13), conservation and sustainable use of ecosystems (SDG 14 and 15), and the use of water and sanitation (SDG 6). On the contrary, the least developed were the promotion of a global alliance (SDG 17), decent work and industrialization (8 and 9), and the promotion of peace and justice (SDG 16). 


\subsection{Competences in Higher Education for SDGs}

Competences can be defined as integration of knowledge, skills, and attitudes that can be applied in a specific context $[17,18,36]$. Competences development should be the basis of educational curricula, including at the university level $[20,22,36,42]$. Competences in the university environment should integrate specific competences (directly related to the degree for which the degree forms) and transversal competences, those that being related to the degree are also related to the development of a critical citizenship [10,19-21].

The development of SDGs requires a balanced development of both types of competences. On the one hand, we need professionals who have knowledge of their specialty, but on the other hand, we need students who know how to position themselves in a globalized and changing world [33]. Students should develop competences such as critical thinking, narrative imagination, and agency, the bases of capability approach [33], or others such as ethical reasoning, the ability to discern the consequences of their actions $[9,10,17]$.

Some authors have argued that competence development is crucial for the training of 21st-century professionals and is highly valued by accreditation agencies [23]. In this approach, education would be an instrumental tool for economic development [7]. The true potential of competence development is its transformative character, since it is intimately related to the exercise of committed, critical, and cosmopolitan citizenship [7].

In order to carry out a design in competences, there are different approaches [37] and methodologies [36]. The correct choice of these methodologies requires an understanding of the needs of the students [43]. Another challenge in competence education is the evaluation of competences, especially in the case of transversal competences [44]. Some approaches have been developed to assess competences in Education for Sustainable Development (ESD) [44]. For example, Waltner et al. proposed a framework with three levels (basic cross curricular sustainability competence, basic subject-specific sustainability competence and elaborated sustainability competence), and 4 dimensions (cognitive, affective-motivational, behavioral, and additional subcompetences) to assess competences in the field of ESD in secondary education [44]. In any case, in order to evaluate competences, it is necessary to know the starting point of the students in order to be able to evaluate the impact of the teaching-learning process [23]. These two aspects justify the need to know in depth the students with whom we are working.

\subsection{Research Questions and Objectives}

Thus, the aim of the work is to answer the following questions: What is the student's level of knowledge of the Sustainable Development Goals? How did the students learn about the Sustainable Development Goals? What is the level of importance students give to SDGs? Are there differences based on the degree the students are studying?

Formally, the main objectives of this work are:

1. To develop and implement an effective tool for measuring the level of knowledge about SDGs.

2. To evaluate the knowledge that university students have about SDGs in three degrees of the University of Extremadura.

3. To study whether there are differences between students who are taking different university degrees.

4. To detect possible demands for training that can be addressed in the university stage.

\section{Methodology}

The current piece of research was an observational work with both descriptive and inferential implications. Since the main aim is to retrieve some realistic data on the SDG reception amongst the youth population within university students, it also presents a retrospective view of this UN Program. 
Three kinds of samples (regarding the studies: Health, Education, and Engineering students) were involved in the work, so it can be considered as multicenter research.

\subsection{Data Collection}

A questionnaire was developed for data collection. This questionnaire is presented in Appendix A. The questionnaire is structured in five blocks of questions. The first of them corresponds to sociological data of the students (Q1-Q6). In the second block of questions (Q7-Q14), the previous knowledge of SDGs is analyzed as well as the source of obtaining this knowledge. Students are then asked about the relationship between SDGs and the profession for which they are being trained (block 3, Q15-Q31), and with their personal lives (block 4, Q32-Q48). Finally, students are asked about the development of the theme of each of the SDGs in university studies (block 5, Q49-Q65). Items Q7-Q65 were answered using a five-point Likert scale ranging from 1 ("Strongly disagree") to 5 ("Completely agree"), in a similar way as previous published works [25].

For the design of the questionnaire, a bibliographic review was first carried out [32]. Subsequently, the draft questionnaire was reviewed by independent experts [45]. Two experts in survey design in the field of Science Education with more than 10 years of teaching and research experience reviewed the questionnaire. They made minor modifications to the wording of the questions. The students filled in online the form anonymously [46], using the Google Form ${ }^{\circledR}$ tool (Google LLC, Mountain View, CA, USA) [25], the response rate ranged from 25 to $35 \%$ These response rates are similar to other studies published in the bibliography $[27,46,47]$. Students were informed of the purpose of the research, and informed consents were obtained.

The questionnaire consists of 2 quantitative variables ( $Q 1$ and $Q 5)$. The other variables are categorical $(Q 2, Q 3$, and $Q 4)$, and ordinal variables $(Q 6-Q 65)$.

\subsection{Sample Description}

In order to achieve the objectives of the research, the sample consisted of students from the Faculty of Medicine [19], the School of Industrial Engineering [20], and the Faculty of Education [48] of the University of Extremadura. The students from the Faculty of Medicine studied the degree in Physiotherapy, the students from the School of Industrial Engineering the degree in Mechanical Engineering, and the students of the Faculty of Education the degree in Primary Education teacher. The choice of these degrees responds to previous work of the authors [48] in which differences were found in the student's motivations. At this point, it is important to consider that this work as part of a project to promote and teach SDGs across the university curriculum. It is a pilot project to establish a baseline of students' knowledge about SDGs. We are aware of the limitation of the sample and, although it does not allow us to draw universal conclusions, it allows us to know the need for the SDGs approach in the university. Students were in the 3rd and 4th year of their undergraduate degree. The average age was 22.79 years old; in the sample, there were students from 20 to 35 years old.

\subsection{Data Process}

In order to analyze obtained data, Statistical Package for Social Science (SPSS) software v. 23 for Windows (IBM, Chicago, IL, USA) was used [49].

The reliability of the questionnaire was analyzed using the Cronbach alpha test. According to studies previously published in the literature, it is considered that a set of items is part of the same construct when an alpha coefficient greater than 0.8 is obtained [50-52].

Subsequently, descriptive analysis of the obtained results was carried out in order to design a global landscape of the sample. After confirming normality by using Levene's test, parametrical inferential analysis was developed in order to see significant differences between groups. Additionally, one-way ANOVA was used for identifying significant differences between three groups according to their study adscription (Education, Health, or Engineering). This was confirmed by using post hoc tests such as Tukey's Test. Significance of each test was at the 0.05 level ( $\alpha=95 \%$ of confidence). 


\section{Results}

\subsection{Questionnaire Validation}

The elaborated questionnaire was designed to measure five different constructs. The first of them (C1) is related to the students' perception of the knowledge of Sustainable Development Goals (involving Q7-Q10). The second one (C2) is related to the source of this knowledge (Q11-Q14). The last three constructs $(C 3, C 4$, and $C 5)$ attempt to measure the degree of relationship perceived by the students between the SDGs and their future professional life $(Q 15-Q 31)$, their personal life $(Q 32-Q 48)$, and the training received in the university environment $(Q 49-Q 65)$, respectively. Table 1 shows the coefficient of reliability alpha of Cronbach for each construct. As can be appreciated, the results show a high level of internal consistency between all items of the same construct, since the Cronbach test value is higher than the cut-off value proposed in previous references [50-52]. This allows obtaining a unique value for each construct equal to the average of the items of each category.

Table 1. Cronbach's alpha coefficient for each construct.

\begin{tabular}{ccc}
\hline Construct & Involved Questions & Cronbach's Alpha \\
\hline C1 & $Q 7-Q 10$ & 0.887 \\
$C 2$ & $Q 11-Q 14$ & 0.859 \\
$C 3$ & $Q 15-Q 31$ & 0.918 \\
$C 4$ & $Q 32-Q 48$ & 0.932 \\
$C 5$ & $Q 49-Q 65$ & 0.919 \\
\hline
\end{tabular}

\subsection{Description of the Results}

As seen before, the analysis can be done by linking the specific results under five constructs (C1-C5). In this sense, Table 2 presents the quantitative results of such approach.

Table 2. Mean of constructs.

\begin{tabular}{ccccc}
\hline \multirow{2}{*}{ Construct } & Topic & Mean (Total) & $\begin{array}{c}\text { Mean } \\
\text { (Eng_Stu) }\end{array}$ & $\begin{array}{c}\text { Mean } \\
\text { (Edu_Stu) }\end{array}$ \\
\hline C1 & Knowledge of SDGs & 1.9181 & 1.7750 & 1.8936 \\
C2 & Sources of information & 1.8046 & 1.7250 & 1.8438 \\
C3 & Professional implication of SDGs & 3.6103 & 3.4737 & 3.9453 \\
C4 & Personal implication of SDGs & 3.7243 & 3.5529 & 3.7752 \\
C5 & Training received at the university & 3.0581 & 2.7794 & 3.2766 \\
\hline
\end{tabular}

Figure 2 shows the mean of $Q 7-Q 10$. In view of the collected data and their analysis, the students seem to have a very limited knowledge of the Sustainable Development Goals (Q7-Q10). In all cases, the mean for all questions inside the first construct is less than 2.5. Something similar can be found in the questions concerning construct 2. In questions Q11-Q14, students expressed their opinion about where they have received information about SDGs (Figure 3). In general, the scores for the four items are quite low, less than 2.1. The item with the lowest score (1.60) is informal training through activities with nonprofit organizations $(Q 14)$, while item $Q 12$ reached the greatest value, corresponding to information through traditional mass media (1.93). 


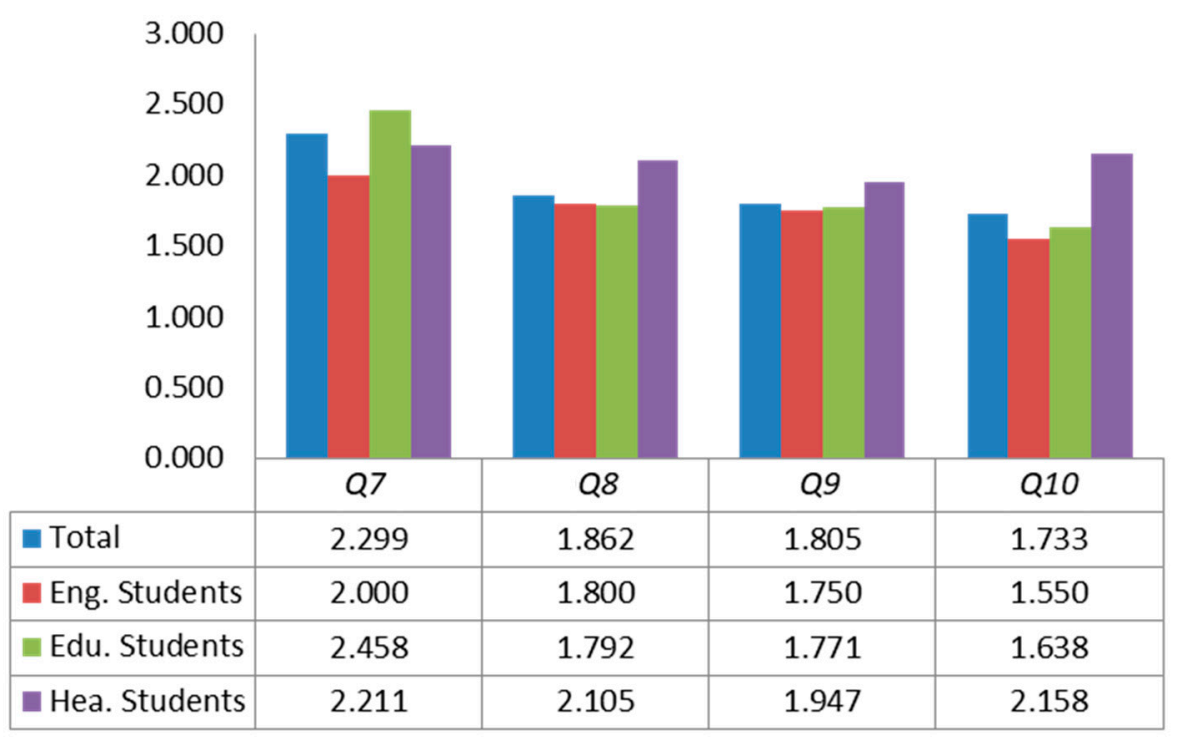

Figure 2. Mean of questions $Q 7-Q 10$ for sample, and different groups.

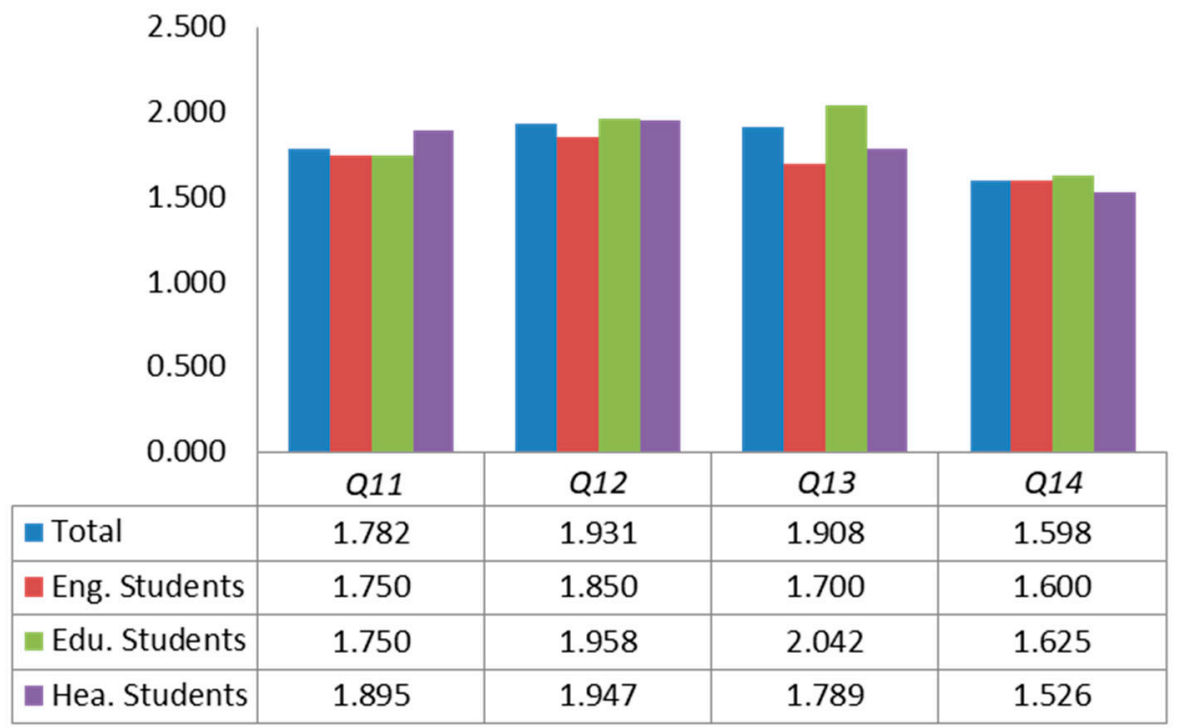

Figure 3. Mean of questions $Q 11-Q 14$ for sample, and different groups.

\subsection{Inferential Analysis}

The relatively high number of subjects of study involved in the study allows us to examine the inferential analysis in order to identify significant differences between variables such as gender, kinds of studies, or the score reached by each construct.

\subsubsection{Different Students: Gender and Kind of Studies}

Bearing in mind the constructs' aggrupation, inferential analysis should drive us to a multiple comparison between groups. For example, the first approach could be to inquire whether there exists or not a significant difference by gender (male should score different from female in some or every construct) or by knowledge area (Health, Engineering, or Education). To do this, a systematic study was carried out involving parametric confirmation (Levene's Test), ANOVA comparison between groups (Male/Female and Health/Engineering/Education) and, in case of significant difference, t-Student for confirmation (for gender) or Tukey post hoc test (for knowledge area). Table 3 shows these results. 
Table 3. Inferential analysis for Gender and Kind of Studies.

\begin{tabular}{|c|c|c|c|c|c|}
\hline Construct & $\begin{array}{l}\text { Levene's Test } \\
\text { Significativity }\end{array}$ & Comparison & $\begin{array}{l}\text { Significativity } \\
(p \text {-Value })\end{array}$ & $\begin{array}{c}\text { Tukey's Post } \\
\text { Hoc Test }\end{array}$ & $\begin{array}{l}\text { T-Student Test } \\
\text { Significativity }\end{array}$ \\
\hline \multirow[t]{2}{*}{ C1 } & \multirow[t]{2}{*}{0.578} & Male/Female & $0.036 *$ & N/A & 0.059 \\
\hline & & Health/Engineering/Education & 0.274 & Unique group & $\mathrm{N} / \mathrm{A}$ \\
\hline \multirow[t]{2}{*}{ C2 } & \multirow[t]{2}{*}{0.150} & Male/Female & 0.588 & $\mathrm{~N} / \mathrm{A}$ & Not needed \\
\hline & & Health/Engineering/Education & 0.787 & Unique group & N/A \\
\hline \multirow[t]{2}{*}{ C3 } & \multirow[t]{2}{*}{0.291} & Male/Female & 0.406 & N/A & Not needed \\
\hline & & Health/Engineering/Education & 0.001 * & HeaEng/EngEdu & N/A \\
\hline \multirow[t]{2}{*}{$C 4$} & \multirow[t]{2}{*}{0.952} & Male/Female & 0.103 & N/A & Not needed \\
\hline & & Health/Engineering/Education & 0.076 & Unique group & N/A \\
\hline \multirow[t]{2}{*}{ C5 } & \multirow[t]{2}{*}{0.463} & Male/Female & 0.116 & N/A & Not needed \\
\hline & & Health/Engineering/Education & 0.079 & Unique group & N/A \\
\hline
\end{tabular}

* Significativity $<0.05$.

As Table 3 shows, every comparison is made on the basis of the parametric analysis, since Levene's test does not reach significativity level in any case. Additionally, the comparison between gender Male/Female does not reveal significant differences between them by ANOVA test except in the case of C1 (Level of SDG knowledge), where $0.036 p$-value is obtained. In order to complete this analysis, $\mathrm{t}$-Student was performed in this case and no differences were obtained between groups. This is a typical example of limited significativity, and in these cases, $\mathrm{t}$-Student criteria is prevalent because it presents stronger consistency since it is specifically applied to 2-groups comparison. Subsequently, no gender differences can be established for the five constructs.

Regarding the intergroups comparison, only the case of C3 (Implications of SDGs for professional life) presented significant differences between the three groups ( $p$-value of 0.001). Tukey's Homogeneous Groups (Tukey's Honestly Significant Differences post hoc test) set out a significant difference between Health students (mean of 2.95 out of 5) and Education students (mean of 3.94 out of 5). Engineering students should appear in an intermediate position (mean of 3.47 out of 5).

\subsubsection{Professional Life Versus Personal Life Implications}

What is the difference between Health and Education students when dealing with SDGs? The abovementioned results could be a slight reflection on how professional implications of SDGs are radically less mentioned and perceived rather than personal life implications. In other words, SDGs are something that has little or nothing to do with my professional life (in case I am not in charge of teaching them!). In order to explore this idea, an analysis for the full sample of $C 3$ (professional implications) and $C 4$ (personal life implications) scores was carried out. A t-Student test revealed significativity ( $p$-value below 0.0001 ), hence both scores are different. Mean of $3.61(C 3)$ versus $3.72(C 4)$ revealed that people involved in this study are aware in the lower level of the implications of SDGs for their professional life rather than what they would have to do with their personal life. The means and standard deviation of questions Q15-Q65 for the total sample and all groups are shown in Appendix B.

Going deeper in the analysis of this concept of personal-professional implications, SDGs and their perception can be submitted to individual analysis, one, and one SDG. Table 4 shows the numerical data regarding these multiple comparisons. 
Table 4. Multiple comparisons according to t-Student test between SDGs and their correlation between professional and personal perception.

\begin{tabular}{|c|c|c|c|c|c|}
\hline \multirow{2}{*}{ SDG } & \multirow{2}{*}{$\begin{array}{l}\text { Mean of Perception of } \\
\text { Professional } \\
\text { Implications }\end{array}$} & \multirow{2}{*}{$\begin{array}{c}\text { Mean of Perception } \\
\text { of Personal } \\
\text { Implications }\end{array}$} & \multirow{2}{*}{$\begin{array}{c}\text { T-Student } p \text {-Value } \\
\text { Comparing } \\
\text { Professional-Personal }\end{array}$} & \multicolumn{2}{|c|}{ Correlation } \\
\hline & & & & $\begin{array}{c}\text { Significativity } \\
\text { Level }\end{array}$ & $\begin{array}{l}\text { Pearson's } \\
\text { Coefficient }\end{array}$ \\
\hline 1 & 2.92 & 3.32 & $0.006^{*}$ & $0.000 *$ & 0.442 \\
\hline 2 & 2.78 & 3.28 & 0.000 * & 0.000 * & 0.440 \\
\hline 3 & 4.27 & 3.97 & 0.019 * & $0.003 *$ & 0.322 \\
\hline 4 & 4.19 & 4.12 & 0.599 & 0.001 * & 0.357 \\
\hline 5 & 4.25 & 4.54 & $0.036^{*}$ & 0.086 & 0.185 \\
\hline 6 & 3.25 & 3.63 & 0.030 * & 0.028 * & 0.235 \\
\hline 7 & 3.33 & 3.52 & 0.235 & $0.016^{*}$ & 0.258 \\
\hline 8 & 4.08 & 3.86 & $0.037 *$ & $0.000 *$ & 0.437 \\
\hline 9 & 3.41 & 3.09 & 0.033 * & 0.000 * & 0.495 \\
\hline 10 & 4.06 & 4.28 & 0.110 & 0.001 * & 0.360 \\
\hline 11 & 3.29 & 3.35 & 0.720 & $0.002 *$ & 0.336 \\
\hline 12 & 3.75 & 3.90 & 0.286 & $0.006^{*}$ & 0.296 \\
\hline 13 & 3.87 & 4.07 & 0.179 & $0.026^{*}$ & 0.241 \\
\hline 14 & 3.22 & 3.58 & 0.054 & $0.022 *$ & 0.248 \\
\hline 15 & 3.47 & 3.85 & 0.019 * & $0.005 *$ & 0.295 \\
\hline 16 & 3.60 & 3.94 & 0.024 * & 0.000 * & 0.479 \\
\hline 17 & 3.59 & 3.68 & 0.472 & 0.000 * & 0.519 \\
\hline
\end{tabular}

In a general way, three considerations must be done:

1. One half of the SDGs reached significativity level when comparing personal and professional implications of each SDG. That is, with statistical relevance differences can be observed between what students scored in perceived personal implications of a particular SDG and the corresponding professional implications of such SDG. $p$-values are under 0.05 except in SDG 4, 7, 10, 11, 12, 13, 14 , and 17.

2. Regarding correlation study, only SDG 5 presented nonsignificant correlation between both variables. That is, when perceived personal and professional implications of each SDG are correlated one to each other, p-values of every correlation are under 0.05 , so the correlation is statistically significant. SDG 5 presented a p-value of 0.086 , so it is also near significativity level.

3. With regard to correlation coefficients, they are quite relevant. Maximum value is observed in SDG 17 (0.519) and the minimum one in SDG 5 (0.185). Note that this last one is the only one out of significativity correlation, as seen before.

4. These results would drive to the conclusion that there exists a strong correlation between both scores, although one (professional perception) scores significantly higher than the other (personal perception).

\section{Discussion}

The main objective of the current work is to evaluate the knowledge that university students have about SDGs; for this aim, a questionnaire was designed. The results shown in the previous section revealed a high consistency in the different constructs that constitute the questionnaire. As far as we know, this is the first questionnaire that is designed for this aim. However, it could be used for other purposes; for example, to evaluate other populations' knowledge, such as primary or secondary teachers, people who work in universities or research centers, etc.

As can be seen from the students' responses to the Q7-Q10 questions, knowledge of SDGs among college students is very limited. This is consistent with the ignorance of the SDGs on the part of the Spanish population [6]. In previous works, Bencini et al. [53] proposed a common language to sensitize university students; on the other hand, they warned of the need to integrate all actors in the educational community including politicians, professors, faculty staff, and students [53].

Students' responses to the Q11-Q14 questions show that there is still room for improvement in the dissemination of SDGs in the university community and for their effective penetration within formal 
and nonformal education. These results show some clues for this task. Although there were initiatives to disseminate SDGs at the university level [4,24-27], these initiatives are not being generalized yet. In our opinion, the role of nongovernmental organizations and cooperation offices is not yet reflected in the results obtained in the university context. On the other hand, at the time of the survey, students had not received information from SDGs via email, social networks, or traditional media, which probably are the most direct ways to reach them. These results indicate that a certain gap can be addressed by all actors. There is no doubt that the SDGs approach must be multidisciplinary $[13,26]$ and multi-stakeholder [7,27], so there must be an adequate coordination, a correct system of governance [26].

With regard to inferential analysis, differences between education students and health students in $\mathrm{C} 3$, we can point out, as a hypothesis, that the multidisciplinary training received by education students could contribute to a greater professional involvement with SDGs. On the other hand, differences may be associated with the nature of the studies, prospective teacher degrees are integrated in Social Sciences and medical studies are associated with the scientific-technical field. Finally, we must point out that there are studies that indicate how education has a clear correlation with other SDGs. These results are consistent with other previous works published in the literature. For example, Langa analyzed the importance and usefulness of transversal skills (ethics and professional deontology, sustainable development, critical thinking, etc.) of 145 preschool and primary teachers with different experience within the Faculty of Educational Sciences of Pitesti University [54]. In this study, significant differences in reference to transversal competences were found in favor of novice teachers as opposed to professionals with greater experience $(t=3.470, d f=143, p=0.001)$ [54]. Thus, such effort of the education faculties in the field of the development of transversal competences seems to be successful. On the other hand, faculties related to scientific-technical studies, such as engineering and health studies, have shown less interest in the development of transversal competences. Another possible explanation for the results obtained may be the following: although there is a sustainable development objective directly related to education (SDG 4), for the achievement of the other sustainable development objectives education has a crucial role, for example, health care (SDG 3), gender equality (SDG 5), in energy saving and the development of renewable energies (SDG 7), health care, and so on [7]. This is attested by the works that relate the various SDGs with education [11]. Despite not having been so studied, there are also (less-direct) links between health or technological development and the rest of the SDGs. This fact has led to the existence of initiatives aimed at promoting the cooperative work of these disciplines with the SDGs as a nexus, with research acting as a transformer lever towards educational excellence $[55,56]$. The reason for this difference should be studied in further works.

Finally, regarding the differences found between the link between professional and personal life with each of the SDGs, it can be said that there are nine goals in which there is a significant difference between what the students think they can contribute with their future professional life and with their personal commitment. However, among SDGs that show significant differences in the average values for the involvement of the SDG in professional and personal life, in SDGs 1, 2, 5, 6, 15, and 16, the means are greater in personal involvement than in professional involvement. On the contrary, in SDGs 3,8 , and 9 , the means are greater in professional involvement than personal involvement. This may be due to the fact that these SDGs include indicators related to specific competences of the three degrees studied by the sample subjects of this study.

In any case, the development of competences in higher education should include specific and transversal competences $[17,19,20]$. The importance of transversal skills has been the subject of interest in many scientific publications [27,57-59]. Strategies for competence development may involve programming a specific subject or developing competences in a transversal way [26]. Although there are drawbacks in the transversal approach of SDGs in the educational field, for example: time (is limited), evaluation, coordination, and teacher training [26,41]; transversal approach to SDGs should be used as UNESCO proposed [60]. Thus, a recent work by Lazzarini et al. [27] indicated that most sustainability interventions were cross-cutting. 
Some authors have indicated as a possible cause of the slowness of the processes, and of the lack of involvement of university professors in promoting sustainability, the lack of recognition that these activities have in the university curriculum and the lack of institutional support [27]. In this sense; in our opinion, advocacy work can be useful for a fair assessment of efforts in this area.

One of the obstacles detected in previous works is the absence of the sustainability in university rankings [61]. With universities increasingly focused on research and competency among them, it is difficult for professors to devote part of their time to activities that promote the sustainability [61]. However, there are some initiatives such as the ranking promoted by Times Higher Education entitled "University Impact Ranking" [13]. This ranking analyzes the degree of commitment of university education institutions to the Sustainable Development Goals. In the first edition published in 2019, 450 universities from 76 countries were analyzed. The first edition published in 2019 analyzed 450 universities from 76 countries. In this edition, 11 SDGs (n. 3-5, 8-13, 16, 17) were analyzed [13]. The existence of this one supposes good news since it puts in an agenda of the institutions of higher education, a subject as important as the sustainability and the Sustainable Development Goals.

\section{Conclusions}

The Sustainable Development Goals constitute a roadmap set by the international community in the next decade. This paper presents a survey that was applied to university students from various degrees: engineering students, teacher training students, and health sciences students. The results obtained show that university students generally say they do not know the Sustainable Development Goals and that the information they have received through various media, including university teaching, social media, social networks, is very scarce.

After carrying out various hypothesis contrasts (both by gender and by studies), only significant differences were found in the case of $C 3$ (professional implications) depending on the studies. Significant differences have been detected in the means between the students of education and those of health sciences. However, students rate less the professional than the personal implications in the achievement of the SDGs.

Studies of the perception of the SDGs at both the professional and professional level have been carried out. The results showed significant differences in most SDGs. They also showed a correlation that is significant in 16 of the 17 SDGs. In this way, the need for the development of both specific and transversal competences is more than justified. In our opinion, the best way to develop these competences is through transversal development in all subjects. As we have defended in the case of teaching ethics, transversal development is a good option to work these competences $[9,10,17,21]$; it allows a greater adaptation to the needs of students. In this way, islands of knowledge are not created (ethics course, sustainability course, or the SDG course); thus, ethics, sustainability, or SDGs must permeate many of the courses, from the basic courses of the first years to the more specialized courses of the last. Although there is a lot of work to be done, there are many initiatives that promote the Sustainable Development Goals at the University $[4,24,25,32]$. This work can contribute to a better evaluation of future initiatives.

This piece of research has also proposed a validated questionnaire that measures the level of knowing about SDGs in a particular sample, in this case, university students. Furthermore, it could be applied to other sections of university community (teachers or administration staff) or even other relevant stakeholders, such as undergraduate students, primary and secondary teachers, etc.

The main limitation of the work lies in the number of surveys obtained and the degrees analyzed. This work is part of a wider project to promote the Sustainable Development Objectives transversally in the degrees of the University of Extremadura.

\section{Practical Implications}

From the analysis and discussion of the results obtained, the following practical implications can be derived for future development: 
1. The students' ignorance of SDGs requires specific training.

2. This training should be understood within the context of Education for Sustainable Human Development.

3. Promotion and teaching of the SDGs requires the development of specific and transversal competences.

4. In our opinion, the development of these competencies should be done transversally throughout the whole curriculum.

5. Both for the evaluation of the development of these competencies and for the planning of the teaching-learning process, the survey developed and presented in this work may be useful.

The work presented shows that there is much to be done at the university level for the promotion of SDGs and coordinated work of all actors will be required. Although the results of this work cannot be universally extrapolated, they show a certain trend that may be of interest to university governing bodies, academics as well as to all agents committed to the implementation of the Sustainable Development Goals. The contribution of the university can be fundamental for the development of the Sustainable Development Goals.

Author Contributions: Conceptualization, F.Z.-P. and J.S.-M.; methodology, F.Z.-P. and L.E.-A.; validation, F.Z.-P.; formal analysis, F.Z.-P. and J.S.-M.; investigation, F.Z.-P. and L.E.-A.; data curation, F.Z.-P. and M.C.-S.; writing-original draft preparation, F.Z.-P., J.S.-M., M.C.-S., and L.E.-A; writing-review and editing, F.Z.-P., J.S.-M., L.E.-A, and M.C.-S.; visualization, F.Z.-P., J.S.-M., and L.E.-A.

Funding: This work was financed by Research Projects EDU2016-77007-R (AEI/FEDER, UE) of the Ministry of Economy and Competitiveness of Spain, and by Research Project IB 16068 and GR18004 of the Regional Government of Extremadura, partially funded by the European Regional Development Fund.

Acknowledgments: The authors thank M. Guerrero-González for her comments and suggestions on the preliminary versions of the manuscript. The authors thank J.P. Parejo-Ayuso and J. Moreno-Losada for their collaboration in compiling the results.

Conflicts of Interest: The authors declare no conflict of interest.

Ethical Approval \& Informed Consent: All procedures performed in studies involving human participants were in accordance with the ethical standards with the 1964 Helsinki Declaration and its later amendments or comparable ethical standards. Informed consent was obtained from all individual participants included in the study.

\section{Appendix A}

Table A1. Sociological questions.

\begin{tabular}{|c|c|c|c|}
\hline Question Number & Question Text & Variable Type & Options \\
\hline$Q 1$ & Age & Quantitative & \\
\hline Q2 & Degree & Categorical & $\begin{array}{l}\text { Physiotherapy Mechanical } \\
\text { Engineering Education }\end{array}$ \\
\hline Q3 & Gender & Categorical & Male Female \\
\hline$Q 4$ & Mode of access to university & Categorical & $\begin{array}{l}\text { A level Professional Vocational } \\
\text { training University degree Other } \\
\text { (Indicate) }\end{array}$ \\
\hline Q5 & University entrance grade & Quantitative & \\
\hline Q6 & $\begin{array}{l}\text { Highest course in which you } \\
\text { are enrolled }\end{array}$ & Ordinal & $1-4$ \\
\hline
\end{tabular}

Indicate the degree of agreement or disagreement with the following statements 
Table A2. Questions about knowledge of SDGs and sources of information.

\begin{tabular}{|c|c|c|c|}
\hline Question Number & Question Text & Variable Type & Options \\
\hline$Q 7$ & $\begin{array}{l}\text { I know what the Sustainable } \\
\text { Development Goals are. } \\
\text { I know the countries to which the }\end{array}$ & Ordinal & ${\text { Likert scale }(1-5)^{1}}^{1}$ \\
\hline Q8 & $\begin{array}{c}\text { Sustainable Development Goals are } \\
\text { addressed. }\end{array}$ & Ordinal & Likert scale $(1-5)^{1}$ \\
\hline$Q 9$ & $\begin{array}{l}\text { I know the time horizon for which the } \\
\text { Sustainable Development Goals are } \\
\text { designed. }\end{array}$ & Ordinal & ${\text { Likert scale }(1-5)^{1}}^{1}$ \\
\hline$Q 10$ & $\begin{array}{l}\text { I know the number of Sustainable } \\
\text { Development Goals and could indicate } \\
\text { one of their goals. }\end{array}$ & Ordinal & ${\text { Likert scale }(1-5)^{1}}^{1}$ \\
\hline Q11 & $\begin{array}{l}\text { I have received information about the } \\
\text { Sustainable Development Goals by } \\
\text { email and/or Social Networks. }\end{array}$ & Ordinal & Likert scale $(1-5)^{1}$ \\
\hline$Q 12$ & $\begin{array}{l}\text { I have received information about the } \\
\text { Sustainable Development Goals from } \\
\text { the traditional media (press, radio } \\
\text { and/or television). }\end{array}$ & Ordinal & Likert scale $(1-5)^{1}$ \\
\hline$Q 13$ & $\begin{array}{l}\text { I have received information about } \\
\text { Sustainable Development Goals in } \\
\text { formal education (high school, } \\
\text { university, etc.). }\end{array}$ & Ordinal & ${\text { Likert scale }(1-5)^{1}}^{1}$ \\
\hline Q14 & $\begin{array}{l}\text { I have received information about the } \\
\text { Sustainable Development Goals in } \\
\text { informal training (e.g., workshops of } \\
\text { NGDOs, actions of the University } \\
\text { Cooperation Office, etc.). }\end{array}$ & Ordinal & Likert scale $(1-5)^{1}$ \\
\hline
\end{tabular}

${ }^{1}$ (1) Strongly disagree, (5) Strongly agree.

Indicate the degree of agreement or disagreement with the following statements.

I consider the profession for which I am training to be related to:

Table A3. Items related with relationship between SDG and profession from students' point of view.

\begin{tabular}{|c|c|c|c|}
\hline Question Number & Question Text & Variable Type & Options \\
\hline Q15 & Poverty reduction & Ordinal & Likert scale $(1-5)^{1}$ \\
\hline Q16 & Hunger reduction & Ordinal & Likert scale $(1-5)^{1}$ \\
\hline$\tilde{Q} 17$ & Health care and wellness & Ordinal & Likert scale $(1-5)^{1}$ \\
\hline Q18 & Quality education & Ordinal & Likert scale $(1-5)^{1}$ \\
\hline$\tilde{Q} 19$ & Gender equality & Ordinal & Likert scale $(1-5)^{1}$ \\
\hline$\tilde{Q} 20$ & Access to clean water and Sewerage & Ordinal & Likert scale $(1-5)^{1}$ \\
\hline$\widetilde{Q} 21$ & Accessible and non-polluting energy & Ordinal & Likert scale $(1-5)^{1}$ \\
\hline Q22 & Decent work and economic growth & Ordinal & Likert scale $(1-5)^{1}$ \\
\hline Q23 & Industry, innovation and infrastructure & Ordinal & Likert scale $(1-5)^{1}$ \\
\hline Q24 & Reducing inequalities & Ordinal & Likert scale $(1-5)^{1}$ \\
\hline Q25 & $\begin{array}{l}\text { Creating sustainable cities and } \\
\text { communities }\end{array}$ & Ordinal & Likert scale $(1-5)^{1}$ \\
\hline Q26 & $\begin{array}{l}\text { Responsible consumption and } \\
\text { production }\end{array}$ & Ordinal & Likert scale $(1-5)^{1}$ \\
\hline Q27 & Weather care & Ordinal & Likert scale $(1-5)^{1}$ \\
\hline Q28 & Care of underwater life & Ordinal & Likert scale $(1-5)^{1}$ \\
\hline$\widetilde{Q} 29$ & Care for life in terrestrial ecosystems & Ordinal & Likert scale $(1-5)^{1}$ \\
\hline Q30 & $\begin{array}{l}\text { Peacebuilding, justice and } \\
\text { corruption-free institutions }\end{array}$ & Ordinal & Likert scale $(1-5)^{1}$ \\
\hline Q31 & $\begin{array}{l}\text { Building alliances to achieve the above } \\
\text { goals }\end{array}$ & Ordinal & Likert scale $(1-5)^{1}$ \\
\hline
\end{tabular}

${ }^{1}$ (1) Strongly disagree, (5) Strongly agree.

Indicate the degree of agreement or disagreement with the following statements.

I think my lifestyle has an impact on the following aspects: 
Table A4. Items related with relationship between lifestyle and SDG.

\begin{tabular}{|c|c|c|c|}
\hline Question Number & Question Text & Variable Type & Options \\
\hline Q32 & Poverty reduction & Ordinal & Likert scale (1-5) ${ }^{1}$ \\
\hline$\widetilde{Q} 33$ & Hunger reduction & Ordinal & Likert scale $(1-5)^{1}$ \\
\hline Q35 & Quality education & Ordinal & Likert scale (1-5) ${ }^{1}$ \\
\hline$\widetilde{Q} 36$ & Gender equality & Ordinal & Likert scale $(1-5)^{1}$ \\
\hline Q37 & Access to clean water and Sewerage & Ordinal & Likert scale (1-5) ${ }^{1}$ \\
\hline Q39 & Decent work and economic growth & Ordinal & Likert scale $(1-5)^{1}$ \\
\hline$\widetilde{Q} 40$ & Industry, innovation and infrastructure & Ordinal & Likert scale (1-5) ${ }^{1}$ \\
\hline$\widetilde{Q} 41$ & Reducing inequalities & Ordinal & Likert scale $(1-5)^{1}$ \\
\hline Q42 & $\begin{array}{l}\text { Creating sustainable cities and } \\
\text { communities }\end{array}$ & Ordinal & Likert scale $(1-5)^{1}$ \\
\hline$Q 43$ & $\begin{array}{l}\text { Responsible consumption and } \\
\text { production }\end{array}$ & Ordinal & Likert scale $(1-5)^{1}$ \\
\hline Q46 & Care for life in terrestrial ecosystems & Ordinal & 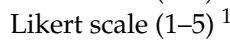 \\
\hline$Q 47$ & $\begin{array}{l}\text { Peacebuilding, justice and } \\
\text { corruption-free institutions }\end{array}$ & Ordinal & Likert scale $(1-5)^{1}$ \\
\hline$Q 48$ & $\begin{array}{l}\text { Building alliances to achieve the above } \\
\text { goals }\end{array}$ & Ordinal & Likert scale $(1-5)^{1}$ \\
\hline
\end{tabular}

${ }^{1}$ (1) Strongly disagree, (5) Strongly agree.

Indicate the degree of agreement or disagreement with the following statements.

I have received training in my university stage on the following topics:

Table A5. Formation received in the university stage related to the SDG questions.

\begin{tabular}{|c|c|c|c|}
\hline Question Number & Question Text & Variable Type & Options \\
\hline$Q 49$ & Poverty reduction & Ordinal & Likert scale $(1-5)^{1}$ \\
\hline Q50 & Hunger reduction & Ordinal & Likert scale $(1-5)^{1}$ \\
\hline$\widetilde{Q} 51$ & Health care and wellness & Ordinal & Likert scale $(1-5)^{1}$ \\
\hline$\widetilde{Q} 52$ & Quality education & Ordinal & Likert scale $(1-5)^{1}$ \\
\hline$\widetilde{Q} 53$ & Gender equality & Ordinal & Likert scale $(1-5)^{1}$ \\
\hline$\widetilde{Q} 54$ & Access to clean water and Sewerage & Ordinal & Likert scale $(1-5)^{1}$ \\
\hline Q55 & Accessible and non-polluting energy & Ordinal & Likert scale $(1-5)^{1}$ \\
\hline$\widetilde{Q} 56$ & Decent work and economic growth & Ordinal & Likert scale $(1-5)^{1}$ \\
\hline Q57 & Industry, innovation and infrastructure & Ordinal & Likert scale $(1-5)^{1}$ \\
\hline Q58 & Reducing inequalities & Ordinal & Likert scale $(1-5)^{1}$ \\
\hline Q59 & $\begin{array}{l}\text { Creating sustainable cities and } \\
\text { communities }\end{array}$ & Ordinal & Likert scale $(1-5)^{1}$ \\
\hline$Q 60$ & $\begin{array}{l}\text { Responsible consumption and } \\
\text { production }\end{array}$ & Ordinal & Likert scale $(1-5)^{1}$ \\
\hline Q61 & Weather care & Ordinal & Likert scale $(1-5)^{1}$ \\
\hline Q62 & Care of underwater life & Ordinal & Likert scale $(1-5)^{1}$ \\
\hline Q63 & Care for life in terrestrial ecosystems & Ordinal & Likert scale $(1-5)^{1}$ \\
\hline Q64 & $\begin{array}{l}\text { Peacebuilding, justice and } \\
\text { corruption-free institutions }\end{array}$ & Ordinal & Likert scale $(1-5)^{1}$ \\
\hline Q65 & $\begin{array}{l}\text { Building alliances to achieve the above } \\
\text { goals }\end{array}$ & Ordinal & Likert scale $(1-5)^{1}$ \\
\hline
\end{tabular}

${ }^{1}$ (1) Strongly disagree, (5) Strongly agree. 


\section{Appendix B}

Table A6. Mean and standard deviation (S.D.) for each of the variables for students of the Faculty of Education (Edu. Students), School of Industrial Engineering (Eng. Students) and Faculty of Medicine (Hea. Students).

\begin{tabular}{|c|c|c|c|c|c|c|c|c|}
\hline \multirow{2}{*}{ Question } & \multicolumn{2}{|c|}{ Edu. Students } & \multicolumn{2}{|c|}{ Eng. Students } & \multicolumn{2}{|c|}{ Hea. Students } & \multicolumn{2}{|c|}{ Total } \\
\hline & Mean & S.D. & Mean & S.D. & Mean & S.D. & Mean & S.D. \\
\hline Q15 & 3.313 & 1.274 & 2.850 & 1.348 & 2.000 & 1.106 & 2.920 & 1.349 \\
\hline Q16 & 3.063 & 1.174 & 2.850 & 1.461 & 2.000 & 1.155 & 2.782 & 1.298 \\
\hline$\widetilde{Q} 17$ & 4.255 & 0.846 & 3.650 & 1.309 & 5.000 & 0.000 & 4.279 & 0.990 \\
\hline Q18 & 4.792 & 0.504 & 3.050 & 1.234 & 3.895 & 1.243 & 4.195 & 1.150 \\
\hline$\widetilde{Q} 19$ & 4.896 & 0.425 & 3.000 & 1.076 & 3.947 & 1.268 & 4.253 & 1.143 \\
\hline$Q 20$ & 3.146 & 1.337 & 4.450 & 0.887 & 2.263 & 1.147 & 3.253 & 1.408 \\
\hline$\widetilde{Q} 21$ & 3.271 & 1.198 & 4.450 & 0.999 & 2.316 & 1.293 & 3.333 & 1.370 \\
\hline$\widetilde{Q} 22$ & 4.063 & 1.080 & 4.105 & 0.994 & 4.105 & 1.049 & 4.081 & 1.043 \\
\hline$Q 23$ & 3.213 & 1.318 & 4.500 & 0.827 & 2.842 & 1.302 & 3.430 & 1.351 \\
\hline$Q 24$ & 4.771 & 0.555 & 2.750 & 1.293 & 3.684 & 1.293 & 4.069 & 1.265 \\
\hline$Q 25$ & 3.319 & 1.321 & 4.100 & 0.968 & 2.474 & 1.264 & 3.314 & 1.340 \\
\hline$Q 26$ & 4.063 & 0.909 & 3.750 & 1.209 & 3.053 & 1.471 & 3.770 & 1.178 \\
\hline$Q 27$ & 4.234 & 0.865 & 4.200 & 0.951 & 2.632 & 1.422 & 3.872 & 1.216 \\
\hline$Q 28$ & 3.739 & 1.324 & 3.150 & 1.424 & 2.053 & 1.224 & 3.224 & 1.475 \\
\hline Q29 & 3.979 & 1.158 & 3.350 & 1.309 & 2.316 & 1.250 & 3.471 & 1.371 \\
\hline Q30 & 4.417 & 0.871 & 2.300 & 1.261 & 2.947 & 1.649 & 3.609 & 1.481 \\
\hline Q31 & 4.125 & 0.890 & 2.900 & 1.294 & 2.944 & 1.474 & 3.593 & 1.268 \\
\hline Q32 & 3.479 & 1.148 & 2.750 & 1.251 & 3.526 & 0.905 & 3.322 & 1.156 \\
\hline Q33 & 3.458 & 1.148 & 2.750 & 1.164 & 3.421 & 1.017 & 3.287 & 1.150 \\
\hline Q34 & 4.000 & 0.945 & 3.350 & 1.137 & 4.526 & 0.697 & 3.966 & 1.017 \\
\hline Q35 & 4.255 & 0.920 & 3.600 & 1.188 & 4.368 & 0.761 & 4.128 & 0.992 \\
\hline Q36 & 4.500 & 0.799 & 4.300 & 0.923 & 4.895 & 0.315 & 4.540 & 0.775 \\
\hline$\tilde{Q} 37$ & 3.667 & 1.059 & 3.650 & 1.309 & 3.526 & 1.307 & 3.632 & 1.163 \\
\hline$\widetilde{Q} 38$ & 3.521 & 1.031 & 3.700 & 1.218 & 3.368 & 1.212 & 3.529 & 1.109 \\
\hline Q39 & 3.896 & 1.016 & 3.500 & 1.277 & 3.947 & 0.911 & 3.816 & 1.062 \\
\hline$Q 40$ & 3.106 & 1.255 & 3.450 & 1.356 & 2.579 & 1.465 & 3.070 & 1.344 \\
\hline$Q 41$ & 4.375 & 0.789 & 3.950 & 1.191 & 4.421 & 0.769 & 4.287 & 0.901 \\
\hline$\widetilde{Q} 42$ & 3.298 & 1.232 & 3.600 & 1.231 & 3.211 & 1.437 & 3.349 & 1.272 \\
\hline$\widetilde{Q} 43$ & 3.917 & 1.069 & 3.900 & 0.968 & 3.889 & 0.963 & 3.907 & 1.013 \\
\hline$Q 44$ & 4.083 & 0.895 & 4.000 & 1.076 & 4.158 & 1.015 & 4.080 & 0.955 \\
\hline$\widetilde{Q} 45$ & 3.458 & 1.414 & 3.700 & 1.342 & 3.789 & 1.134 & 3.586 & 1.334 \\
\hline$\widetilde{Q} 46$ & 3.938 & 1.080 & 3.550 & 1.191 & 3.947 & 1.026 & 3.851 & 1.095 \\
\hline$\widetilde{Q} 47$ & 4.167 & 0.859 & 3.350 & 1.268 & 4.000 & 1.202 & 3.943 & 1.082 \\
\hline$Q 48$ & 3.854 & 1.010 & 3.300 & 1.302 & 3.632 & 1.300 & 3.678 & 1.156 \\
\hline$\widetilde{Q} 49$ & 2.813 & 1.394 & 1.600 & 0.754 & 1.947 & 1.079 & 2.345 & 1.310 \\
\hline$\widetilde{Q} 50$ & 2.792 & 1.304 & 1.700 & 0.923 & 1.895 & 1.100 & 2.345 & 1.274 \\
\hline$\widetilde{Q} 51$ & 4.106 & 0.938 & 2.150 & 0.988 & 4.579 & 1.017 & 3.756 & 1.319 \\
\hline$\widetilde{Q} 52$ & 4.083 & 1.145 & 2.800 & 1.005 & 3.789 & 1.228 & 3.724 & 1.236 \\
\hline$\widetilde{Q} 53$ & 4.292 & 0.874 & 2.350 & 1.226 & 3.842 & 1.302 & 3.747 & 1.314 \\
\hline$\widetilde{Q} 54$ & 2.813 & 1.331 & 3.500 & 1.051 & 2.421 & 1.427 & 2.885 & 1.333 \\
\hline$\widetilde{Q} 55$ & 3.083 & 1.318 & 4.100 & 0.912 & 2.158 & 1.167 & 3.115 & 1.359 \\
\hline$\widetilde{Q} 56$ & 3.250 & 1.101 & 3.150 & 1.226 & 3.421 & 1.346 & 3.264 & 1.176 \\
\hline$\widetilde{Q} 57$ & 2.708 & 1.288 & 4.300 & 0.801 & 2.842 & 1.259 & 3.103 & 1.347 \\
\hline$\widetilde{Q} 58$ & 4.188 & 1.045 & 2.050 & 0.999 & 3.526 & 1.307 & 3.552 & 1.387 \\
\hline$\widetilde{Q} 59$ & 2.813 & 1.266 & 3.150 & 1.226 & 2.263 & 1.327 & 2.770 & 1.291 \\
\hline$\widetilde{Q} 60$ & 3.271 & 1.333 & 3.300 & 1.174 & 2.789 & 1.437 & 3.172 & 1.322 \\
\hline$\widetilde{Q} 61$ & 3.500 & 1.167 & 3.450 & 1.538 & 2.684 & 1.376 & 3.310 & 1.332 \\
\hline$\widetilde{Q} 62$ & 2.479 & 1.384 & 2.650 & 1.599 & 2.053 & 1.177 & 2.425 & 1.395 \\
\hline$\widetilde{Q} 63$ & 3.208 & 1.288 & 2.950 & 1.572 & 2.211 & 1.182 & 2.931 & 1.379 \\
\hline$\widetilde{Q} 64$ & 3.646 & 1.062 & 1.950 & 1.191 & 2.632 & 1.342 & 3.034 & 1.351 \\
\hline Q65 & 3.208 & 1.166 & 2.100 & 1.210 & 2.737 & 1.522 & 2.851 & 1.325 \\
\hline
\end{tabular}




\section{References}

1. Sachs, J.D. From millennium development goals to sustainable development goals. Lancet 2012, 379, 2206-2211. [CrossRef]

2. General Assembly of United Nations. Transforming Our World: The 2030 Agenda for Sustainable Development. Resolution Adopted by the General Assembly on 25 September 2015. Available online: http://www.un.org/ga/search/view_doc.asp?symbol=A/RES/70/1\&Lang=E (accessed on 7 November 2018).

3. Brissett, N.; Mitter, R. For function or transformation? A critical discourse analysis of education under the Sustainable Development Goals. J. Crit. Educ. Policy Stud. 2017, 15, 181-204.

4. Weybrecht, G. From challenge to opportunity-Management education's crucial role in sustainability and the Sustainable Development Goals-An overview and framework. Int. J. Manag. Educ. 2017, 15, 84-92. [CrossRef]

5. Spanish Government. Action Plan for the Implementation of Agenda 2030. Towards a Spanish Sustainable Development Strategy; Spanish Government: Madrid, Spain, 2018.

6. Centro de Investigaciones Sociológicas. Barometer January 2019; CIS: Madrid, Spain, 2019.

7. Dlouhá, J.; Pospíšilová, M. Education for Sustainable Development Goals in public debate: The importance of participatory research in reflecting and supporting the consultation process in developing a vision for Czech education. J. Clean. Prod. 2018, 172, 4314-4327. [CrossRef]

8. Hortal, A. Ética General de las Profesiones; Desclée De Brouwer: Bilbao, Spain, 2002; ISBN 9788433017185.

9. Sánchez-Martín, J.; Zamora-Polo, F.; Moreno-Losada, J.; Parejo-Ayuso, J.P. Innovative education tools for developing ethical skills in university science lessons. The case of the moral cross dilemma. Ramon Llull J. Appl. Ethics 2017, 8, 225-245.

10. Sánchez-Martín, J.; Zamora-Polo, F.; Moreno-Losada, J. Including ethical learning and moral reasoning aspects in higher education: A proposal for developing ethical competences in the university. In Business Intelligence, Strategies and Ethics; Nova Science Publishers: New York City, NY, USA, 2015; ISBN 9781634820646.

11. Vladimirova, K.; Le Blanc, D. Exploring links between education and sustainable development goals through the lens of UN flagship reports. Sustain. Dev. 2016, 24, 254-271. [CrossRef]

12. Boni, A.; Lopez-Fogues, A.; Walker, M. Higher education and the post-2015 agenda: A contribution from the human development approach. J. Glob. Ethics 2016, 12, 17-28. [CrossRef]

13. Gusmão Caiado, R.G.; Leal Filho, W.; Quelhas, O.L.G.; Luiz de Mattos Nascimento, D.; Ávila, L.V. A literature-based review on potentials and constraints in the implementation of the sustainable development goals. J. Clean. Prod. 2018, 198, 1276-1288. [CrossRef]

14. Owens, T.L. Higher education in the sustainable development goals framework. Eur. J. Educ. 2017, 52, 414-420. [CrossRef]

15. Martínez-Martínez, J.L. Ética en la universidad: El horizonte de la Agenda 2030 y de la Ecología Integral. Razón y Fe 2019, 279, 285-298.

16. Manzano-Arrondo, V. La Universidad Comprometida; Hegoa: Vitoria, Spain, 2012; ISBN 9788489916715.

17. Zamora-Polo, F.; Sánchez-Martín, J.; Hipólito-Ojalvo, F. Using moral dilemma for ethical skills development in engineering degrees. Application to mechanical engineering. DYNA Ingenieria e Industria 2016, 91, 495-497. [CrossRef]

18. Mateos, V.L.; Montanero, M.; Gómez, V.; Salamanca, S. Diseño e Implantación de Títulos de Grados en el Espacio Europeo de Educación Superior; Ediciones Narcea: Madrid, Spain, 2008; ISBN 978-84-277-1629-2.

19. Zamora-Polo, F.; Román-Suero, S.; Sánchez-Martín, J. From efficiency to sustainability. Training responsible engineers in the new educational scene. DYNA Ingenieria e Industria 2010, 85, 575-580. [CrossRef]

20. Zamora-Polo, F.; Luque-Sendra, A.; Sánchez-Martín, J.; Aguayo-González, F. Conceptual framework for the use of building information modeling in engineering education. Int. J. Eng. Educ. 2019, 35, 744-755.

21. Zamora-Polo, F.; Sánchez-Hernández, M.I.; Gallardo-Vázquez, D.; Hipólito-Ojalvo, F. Formando ciudadanos comprometidos. Fomento de la responsabilidad social en los universitarios. Revista Interuniversitaria de Formación del Profesorado 2014, 28, 51-62.

22. Zamora-Polo, F.; Sánchez-Martín, J. Analysis of the implementation of the master of industrial engineering in Spain. What an engineer should know? What we teach? DYNA Ingenieria e Industria 2015, 90, 153-157. [CrossRef] 
23. Gnaur, D.; Svidt, K.; Thygesen, M.K. Developing students' collaborative skills in interdisciplinary learning environments. Int. J. Eng. Educ. 2015, 31, 257-266.

24. Crespo, B.; Míguez-Álvarez, C.; Arce, M.E.; Cuevas, M.; Míguez, J.L. The sustainable development goals: An experience on higher education. Sustainability 2017, 9, 1353. [CrossRef]

25. Ortega-Sánchez, D.; Gómez-Trigueros, I. Massive open online courses in the initial training of social science teachers: Experiences, methodological conceptions, and technological use for sustainable development. Sustainability 2019, 11, 578. [CrossRef]

26. Annan-Diab, F.; Molinari, C. Interdisciplinarity: Practical approach to advancing education for sustainability and for the sustainable development goals. Int. J. Manag. Educ. 2017, 15, 73-83. [CrossRef]

27. Lazzarini, B.; Pérez-Foguet, A.; Boni, A. Key characteristics of academics promoting sustainable human development within engineering studies. J. Clean. Prod. 2018, 188, 237-252. [CrossRef]

28. Sen, A. Development as Freedom; Oxford University Press: Oxford, UK, 1999; ISBN 978-0-19-289330-7.

29. World commission on environment and development our common future-Report of the World Commission on Environment and Development (The Brundtland Report). Med. Confl. Surviv. 1987. [CrossRef]

30. UNDP. Human Development Report 2011. Sustainability and Equity: A Better Future for All; UNDP: New York, NY, USA, 2011; ISBN 9780230363311.

31. Lozano, R.; Young, W. Assessing sustainability in university curricula: Exploring the influence of student numbers and course credits. J. Clean. Prod. 2013, 49, 134-141. [CrossRef]

32. Pérez-Foguet, A.; Lazzarini, B.; Giné, R.; Velo, E.; Boni, A.; Sierra, M.; Zolezzi, G.; Trimingham, R. Promoting sustainable human development in engineering: Assessment of online courses within continuing professional development strategies. J. Clean. Prod. 2018, 172, 4286-4302. [CrossRef]

33. Boni, A.; Calabuig, C. Education for global citizenship at universities. J. Stud. Int. Educ. 2017, 21, 22-38. [CrossRef]

34. Pérez-Foguet, A.; Lazzarini, B. Continuing professional education in engineering faculties: Transversal integration of sustainable human development in basic engineering sciences courses. J. Clean. Prod. 2019, 218, 772-781. [CrossRef]

35. Boni, A.; Pérez-Foguet, A. Introducing development education in technical universities: Successful experiences in Spain. Eur. J. Eng. Educ. 2008, 33, 343-354. [CrossRef]

36. Lozano, R.; Merrill, M.; Sammalisto, K.; Ceulemans, K.; Lozano, F. Connecting competences and pedagogical approaches for sustainable development in higher education: A literature review and framework proposal. Sustainability 2017, 9, 1889. [CrossRef]

37. Lozano, F.J.; Lozano, R. Developing the curriculum for a new Bachelor's degree in Engineering for Sustainable Development. J. Clean. Prod. 2014, 64, 136-146. [CrossRef]

38. Sen, A. Inequality Reexamined; Oxford University Press: Oxford, UK, 1992.

39. Nussbaum, M.C. Women and Human Development; Cambridge University Press: Cambridge, UK, 2000; ISBN 9780511841286.

40. Albareda-Tiana, S.; Vidal-Raméntol, S.; Pujol-Valls, M.; Fernández-Morilla, M. Holistic approaches to develop sustainability and research competencies in pre-service teacher training. Sustainability 2018. [CrossRef]

41. Rampasso, I.S.; Siqueira, R.G.; Anholon, R.; Silva, D.; Quelhas, O.L.G.; Leal Filho, W.; Brandli, L.L. Some of the challenges in implementing Education for Sustainable Development: Perspectives from Brazilian engineering students. Int. J. Sustain. Dev. World Ecol. 2019, 1-10. [CrossRef]

42. Bohlinger, S. Competences as the core element of the European Qualifications Framework. Eur. J. Vocat. Train. 2008.

43. Melo, L.; Cañada, F.; Mellado, V. Exploring the emotions in Pedagogical Content Knowledge about the electric field. Int. J. Sci. Educ. 2017, 39, 1025-1044. [CrossRef]

44. Waltner, E.-M.; Rieß, W.; Mischo, C. Development and validation of an instrument for measuring student sustainability competencies. Sustainability 2019, 11, 1717. [CrossRef]

45. Meng, M.; Peter, D.; Mattner, F.; Igel, C.; Kugler, C. Development and psychometric pilot-testing of a questionnaire for the evaluation of satisfaction with continuing education in infection control nurses. Nurse Educ. Pract. 2018, 31, 77-82. [CrossRef] [PubMed]

46. Wu, W.; Issa, R.R.A. BIM Education and recruiting: Survey-based comparative analysis of issues, perceptions, and collaboration opportunities. J. Prof. Issues Eng. Educ. Pract. 2014, 140, 04013014. [CrossRef] 
47. López-Zaldívar, O.; Verdú-Vázquez, A.; Gil-López, T.; Lozano-Diez, R.V. The implementation of building information modeling technology in university teaching: The case of the Polytechnic University of Madrid. Int. J. Eng. Educ. 2017, 33, 712-722.

48. Zamora-Polo, F.; Sánchez-Martín, J.; Espejo-Antúnez, L. Motivaciones de los estudiantes universitarios. Estudio de caso de estudiantes de Ingeniería Mecánica, Fisioterapia y Educación Primaria. In III Jornadas Ética y Universidad; Science Faculty: Badajoz, Spain, 2016.

49. SPSS. SPSS 23.0. Developer's Guide; SPSS: Chicago, IL, USA, 2015.

50. Lai, H.-M.; Hsiao, Y.-L.; Hsieh, P.-J. The role of motivation, ability, and opportunity in university teachers' continuance use intention for flipped teaching. Comput. Educ. 2018, 124, 37-50. [CrossRef]

51. Peterson, R.A. A meta-analysis of cronbach's coefficient alpha. J. Consum. Res. 1994. [CrossRef]

52. Nunnally, J.C.; Bernstein, I.H. Psychometric Theory; McGraw-Hill: New York, NY, USA, 1967; Volume 226.

53. Bencini, G.M.L.; Garofolo, I.; Arenghi, A. Implementing universal design and the ICF in higher education: Towards a model that achieves quality higher education for all. Stud. Health Technol. Inf. 2018, 256, 464-472.

54. Langa, $\mathrm{C}$. The contribution of transversal competences to the training of the educational sciences specialist. Procedia-Soc. Behav. Sci. 2015, 180, 7-12. [CrossRef]

55. Clifford, K.L.; Zaman, M.H. Engineering, global health, and inclusive innovation: Focus on partnership, system strengthening, and local impact for SDGs. Glob. Health Action 2016, 9, 30175. [CrossRef] [PubMed]

56. Lees, J.; Webb, G.; Coulston, F.; Smart, A.; Remedios, L. Health professional workforce education in the Asia Pacific. J. Public Health Res. 2016, 5, 658. [CrossRef] [PubMed]

57. Taajamaa, V.; Majanoja, A.-M.; Bairaktarova, D.; Airola, A.; Pahikkala, T.; Sutinen, E. How engineers perceive the importance of ethics in Finland. Eur. J. Eng. Educ. 2018, 43, 90-98. [CrossRef]

58. Monteiro, F.; Leite, C.; Rocha, C. The influence of engineers' training models on ethics and civic education component in engineering courses in Portugal. Eur. J. Eng. Educ. 2017, 42, 156-170. [CrossRef]

59. Olmedo-Torre, N.; Martínez, M.M.; Perez-Poch, A.; García, B.A. Perception of the acquisition of generic competences in engineering degrees. Int. J. Technol. Des. Educ. 2018, 28, 495-506. [CrossRef]

60. UNESCO. Education for Sustainable Development Goals. Learning Objectives. Available online: http: //unesdoc.unesco.org/images/0024/002474/247444e.pdf (accessed on 7 November 2018).

61. Lazzarini, B.; Pérez-Foguet, A. Profiling research of the engineering academics who successfully promote education in sustainable human development. J. Clean. Prod. 2018, 172, 4239-4253. [CrossRef] 